
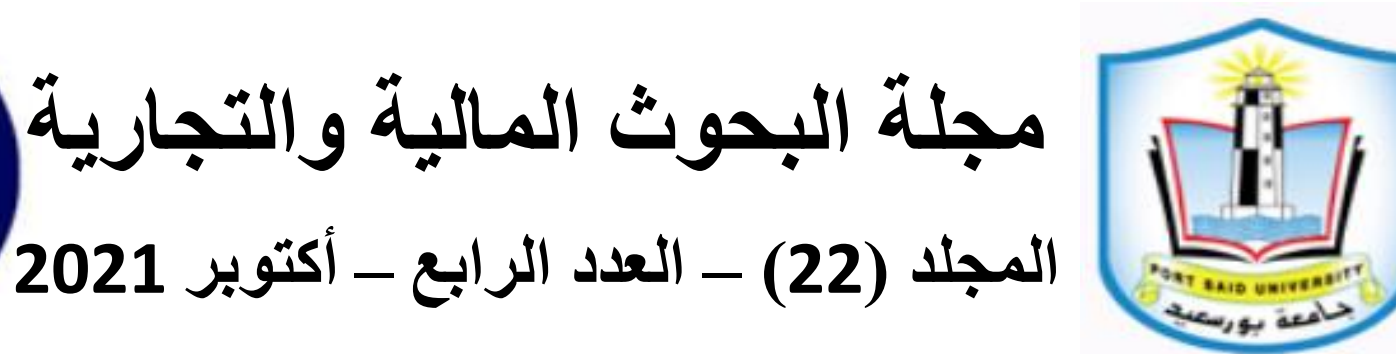

\title{
Individual Readiness for Change; the Dyadic of Transformational Leadership and Ambidextrous Behaviors
}

\author{
Hamada Fawzy Abuzid ${ }^{1}$ and Reem Zoheir Abu-Tabl ${ }^{2}$ \\ 1 Associate Professor of Business Administration and chairperson of \\ Business Administration department, Faculty of Commerce, Benha \\ University, Egypt. \\ ${ }^{2}$ Lecturer Faculty of Management, Economics and Information systems, \\ MUST University, Egypt.
}




\section{Abstract}

Purpose - This paper investigates the influence of transformational and ambidextrous behaviors on individual readiness for change within the context of work related changes induced by quality assurance and accreditation attempts in Egyptian Universities.

Methodology - A self-reported survey was distributed to faculty members in four Egyptian Universities (two private and two public), 500 surveys were distributed and 435 were collected. Data was analyzed using SPSS/AMOS statistical software.

Findings - Results showed that transformational leadership had a positive effect on individual readiness for change moderated by ambidextrous behaviors. The empirical investigation revealed varying impacts of multiple research constituents.

Research implications - Despite the documented importance of individual readiness for change in the management literature, scare research was found regarding the role of effective leadership styles in the context of universities nevertheless in Egypt. This study serves as a strong foundation for future research in this area, which is at its nascence and upcoming in the researchers' community.

Practical implications - Leaders need to set clear agenda and effectively communicate the appropriateness and benefits of change to their subordinates for developing positive behaviors towards desirable organizational outcomes.

Originality - This paper attempts to determinate both transformational and ambidextrous leaders' behaviors influencing subordinates readiness to embark on work changes related to quality assurance and accreditation in Egyptian universities.

Keywords - Readiness for change, Transformational leadership, Ambidextrous leadership.

Paper type - Research paper. 


\section{Introduction}

Organizational readiness for change (ORFC) has been documented in the management literature as a critical precursor to the successful implementation of change initiatives (Mueller et al., 2012; Haffar et al., 2014; Hemme et al., 2018). Several studies attempted to categorize ORFC aiming at a thorough comprehension of its constituents (Rusly et al., 2012; Gurumurthy et al., 2013; Haque et al., 2016) where a multi-level approach was elaborated in the study of Samal et al., (2019) highlighting three levels of readiness; individual (psychological inclination), group (collective perception) and organizational (systems, structure, processes, leadership and culture).

According to Vakola, (2013) ignoring the relationships between constituents may lead to ineffective change implementation. Consequently, a motivation was triggered for this research to address the association between leadership "organizational level" and "individual" readiness for change (IRFC) for the presumed importance of their roles in implementing changes; leaders, responsible and accountable for organizational changes "OC" (Nogueira et al., 2018; Surty and Scheepers, 2020) and individuals effecting them (Shokri et al., 2016; Douglas et al., 2017).

Numerous researches have studied the association between different leadership styles and change dynamics where transformational leadership (TL) was witnessed to better foster changes (Abrell-Vogel and Rowold, 2014; Matzler et al., 2015; Burawat, 2019; Schell, 2019; Zaman, 2020; Busari et al., 2020). However, the complexity of business environments called for a new leadership paradigm stressing on a simultaneous balance between exploiting current knowledge and exploring new on both individual and organizational levels where subsequently the concept of Ambidextrous Leadership (AL) emerged (Rosing et al., 2011). On the AL individual platform, studies of Li et al., 2015; Baskarada et al., 2016; Zheng et al., 2016; Berraies and Abdine, 2019 recognized the value of TL in promoting AL activities.

Furthermore, the researchers were motivated to empirically investigate the higher education sector (HES) where realizing strategic changes entails multiple challenging phenomena (Stensaker et al., 2014; Smulowitz, 2015; 
O'Donnell, 2016). Nevertheless, effective leadership styles in the context of HES have not been well articulated in the leadership literature (Hassan et al., 2018; Barrett et al., 2019). Therefore, the purpose of this study is to investigate the impact of TL behaviors on IRFC moderated by AL behaviors in Egyptian universities.

\section{Literature Review}

\section{ORFC}

Change has become an inescapable reality for organizations pursuing sustainable survival in contemporary business environments. In quintessence, Al-Haddad and Kotnour (2015) proposed a four-facet taxonomy classifying the OC literature; change type (scale and duration), change enablers (factors increasing the probability of change success), change methods (management and systematic) and change outcomes (results or consequences). Among "change enablers", ORFC was asserted to affect change success by; enhancing employees attitudes and commitment (Rafferty et al., 2013), motivating employees to embark on (Rusly et al., 2015), preempting the likelihood of resistance (Adil, 2016; Thakur and Srivastava, 2018), improving business performance and growth (Timmor and Zif, 2010; Haque et al., 2016).

Armenakis et al. (1993) defined ORFC as an individual's "beliefs, attitudes, and intentions regarding the extent to which changes are needed and the organization's capacity to successfully undertake those changes" (p. 681). Consequently, the genesis of ORFC encompasses a psychological state of mind and a cognitive evaluation of proposed changes manifested in "individual" and aggregate (group) behaviors to accept (passively/actively) or resist such changes influenced by organizational-level systems and capabilities.

\section{$\underline{1.1 \text { IRFC }}$}

According to O'Reilly et al., (2018), ignoring the pivotal role IRFC in activating changes was diagnosed as a crucial failure factor for effective change implementation. A five dimensional construct was highlighted in the studies of Armenakis and Harris (2002) and Holt et al., (2007) comprising; 
valence and appropriateness "VA" (content factors), management support (process factors), personal benefits "PB" and self efficacy (individual factors).

According to Holt et al., (2007) valence refers to the extent to which employees feel that change is beneficial to the organization. Subsequently, the need for change must be elaborated where discrepancies between current and ideal or desired state is articulated. Moreover, individual's assessment of the appropriateness of the chosen change initiative (type, scope and feasibility) is of imperative importance. Self and Schraeder (2009) reported that management must provide individuals with the information required to judge a change initiative as the correct one. Whereas management support enhances individuals acceptance, turnout for and indulgence in change initiatives. Means of support may include managers communicating the importance of individuals' roles in change implementation (Antony et al., 2012), allocation of sufficient resources (quantitatively and qualitatively), effective visible involvement of principal (manager) during implementation (Antony, 2014), and removing or at least neutralizing obstacles which might be encountered during implementation (Albliwi et al., 2014).

According to Lehman et al., (2002) individuals assess change subjected to its impact on one's own good "Personal benefits" by comparing between benefits accrued to self against corresponding costs and risk incurred. Benefits perceived is a function of favorable status change, rewards and incentives and gained knowledge and skills (Self and Schraeder, 2009). On the other hand, costs incurred are in terms of time spent, effort exerted, benefits forgone (monetary and non-monetary), uncertainty associated with individual future with the organization, relationship with co-workers, and the impact of changes on organizational wellbeing (Haffar et al., 2014). Furthermore, when faced with change individuals assess their self-efficacy by frequently questioning their own abilities to successfully implement changes (Costello and Arghode, 2020). As such, efficacy is a function of aggregate individual's belief on implementation capability of self, organizational resources and situational factors (Abuzid and Abbas 2016).

Multiple influential factors were highlighted by Vaishnavi et al., (2019) affecting IRFC construct where scrutinized leadership manipulation of 
varying practices may enhance and catalyze individual readiness; communication, resource availability, education and training, reward system, employee involvement, organizational mission and goals, interdependence among departments, technological infrastructure, culture, and stress level and job security.

\subsection{Leadership and IRFC}

In essence, Leadership is accountable for steering OC where Katsaros et al., (2020) concluded that different leadership styles have varying impacts on how management reverberate IRFC. Baskarada et al., (2017) identified four organizational factors (human capital, performance, time orientation and risk appetite) and two environmental factors (risk and stability) affecting leadership styles embraced to embark on changes. In addition, Loh et al., (2019) claimed that different contingencies either situational or problematic influence chosen styles, nevertheless, leader own philosophy, personality and experience.

\section{TL}

TL was postulated as more appropriate to effectuate changes (Busari et al., 2020; Katsaros et al., 2020) building on its constructive contributions under turbulent and uncertain environments (Raziq et al., 2018), poor organizational performance, periods of organizational inception/decline or renewal (Vera and Crossan, 2004; Jansen et al., 2006; Jansen et al., 2009) where TL creates vision and strategy, enhance devotion to the vision, and flexibly and dynamically coordinate resources and capabilities portfolio.

Avolio et al., (2009, p. 423) defined TL as "leader behavior that transform and inspire followers to perform beyond expectations while transcending self-interest for the good of the organization". Transformational leaders provide positive changes on followers' beliefs, values, personal disposition, perceptions, expectations (Mohammed et al., 2012; Munir et al., 2012) and enhance trust and cooperation among followers (Green et al., 2014; Boehm et al., 2015). In the seminal work of Bass (1985) four dimensions of TL were identified, where only leaders who effectively amalgamate their behaviors manifested in all domains can reap TL benefits: 
Idealized influence (II) is the degree to which leaders behave in admirable ways so that followers identify with and trust the leader (Bass, 1985). Leaders serve as role models with high ethics, act in a way that is consistent with the articulated vision (Matzler et al., 2015; Burawat, 2019), display conviction, demonstrate determination and instill pride (Berriaes and Abdine, 2019). Inspirational motivation (IM) is the degree to which a leader articulates a shared vision that appeals and inspires followers (Bass, 1985). Leaders stimulate followers to perform better and provoke their consciousnesses of problems (Berriaes and Abdine, 2019; Zaman et al., 2020). Leaders challenge followers by setting high standards and expectations (Matzler et al., 2015), communicate optimism about future goals and provide meaning tasks on hand (Schell, 2019). Intellectual stimulation (IS) is the degree to which a leader stimulates followers to initiate new ideas and creative solutions thereby questioning assumptions, reframing problems from new perspectives and encouraging risk taking (Bass, 1985). It enhances followers' capabilities to conceptualize, comprehend and discern the nature of encountered problems allowing innovative solutions and means of implementation (Schell, 2019). Individualized consideration (IC) is the degree to which leaders understand the individual needs of each of their followers and attend to those needs (Bass, 1985). Leaders tailor the level of recognition and support to both the needs and preferences of each employee (Schell, 2019), they provide encouragement, training, learning and selfdevelopment, and personalized coaching and esteem which may lead every employee to attain one's fullest potential (Li et al., 2015).

Although scarce research was found addressing the association between TL and IRFC, favorable impacts were reported by Al-Hussami et al., (2017) who investigated the influence of TL competencies and quality of work on employees readiness and Al-Hussami et al., (2018) who incorporated the influence of TL behaviors, commitment and support. However, both studies depended on assessing readiness by examining employees' margin in life and demographic variables solely with no regard to the aforementioned construct of IRFC. While Appelbaum et al., (2015a); Appelbaum et al., (2015b) investigated the influence of TL, transactional leadership on employees resistance and their links to organizational outcomes. They proposed a multidimensional model of leadership enhancing IRFC thereby overcoming the antecedents of resistance, where leaders transacts with employees' natural and contextual predisposition to change, prior to, throughout and following 
transformational processes of all scales. Accordingly, the following hypothesis is formulated;

$\mathbf{H}_{1}$ : Transformational leadership has a positive impact on individual readiness for change within research population under investigation.

However, our study is concerned with examining the impact of the TL exclusively on VA and PB as concluded to be the two most compelling elements affecting IRFC. A positive association was reported by Adil et al., 2016; Hemme et al., 2018; Samal et al. (2019) between VA and successful implementation of change. Hemme et al., 2018 further concluded that VA sentiments had an emphasizing impact on self-efficacy beliefs. Moreover, Adil et al., (2016) concluded that understanding VA of OC affects employees perception on how beneficial it is to their individual career $\mathrm{PB}$, a conclusion which was also documented by Samal et al., (2019). Subsequently, the following sub-hypotheses are formulated:

$\mathbf{H}_{1 \mathbf{a}}$ : Individualized Influence has a positive impact on valence and appropriateness within research population under investigation.

$\mathbf{H}_{1 \mathbf{b}}$ : Individualized Influence has a positive impact on personal benefits within research population under investigation.

$\mathbf{H}_{1 \mathbf{c}}$ : Inspirational Motivation has a positive impact on valence and appropriateness within research population under investigation.

H1d: Inspirational Motivation has a positive impact on personal benefits within research population under investigation.

$\mathbf{H}_{1 \mathrm{e}}$ : Intellectual Stimulation has a positive impact on valence and appropriateness within research population under investigation.

$\mathbf{H}_{1 \mathbf{f}}$ : Intellectual Stimulation has a positive impact on personal benefits within research population under investigation.

$\mathbf{H}_{\mathbf{1 g}}$ : Individualized Consideration has a positive impact on valence and appropriateness within research population under investigation.

$\mathbf{H}_{\mathbf{h}}$ : Individualized Consideration has a positive impact on personal benefits within research population under investigation. 


\section{Ambidextrous Behaviors}

TL has been criticized for its insufficient specification of situational variables neglecting boundary conditions which might moderate its effect (Bayraktar and Jimenez, 2020). Accordingly, it can be inferred that TL lacks proper attention to environmental dynamism where a balance between preservation and innovation must be maintained equally effective. Such ambidexterity is a foremost leadership challenge since they play a critical role as an interface for knowledge flow between people, processes and systems (Probst et al., 2011; Bonesso et al., 2014). Rosing et al., (2011) introduced $\mathrm{AL}$ as a new leadership paradigm where its advantages have been articulating in the literature since its inception. Favorable impacts of AL were documented on entrepreneurial orientation and operational performance (Abuzid, 2019), entrepreneurial orientation and job crafting (Luu et al., 2019a) corporate social responsibility and service excellence (Luu et al., 2019b), employee creativity (Tung, 2016), innovation (Berraies and Abdine, 2019; Zuraik and Kelly, 2019).

Rosing et al., (2011) defined AL as the interaction between two complementary leadership behaviors - opening and closing - which can foster both exploratory and exploitive forces. Zacher and Rosing (2015) further elaborated that $\mathrm{AL}$ Behaviors $(\mathrm{AB})$ comprises three components; opening leadership behaviors (OLB) to cultivate exploration, closing leadership behaviors (CLB) to cultivate exploitation and the flexibility and the adaptability to switch between both as the situation demands. According to Luu et al., (2017, p.231), Baum et al., (2000) defined exploitation as "learning gained via local search, experiential refinement, and selection and reuse of existing routines" while exploration as "learning gained through processes of concerted variation, planned experimentation, and play".

On one hand, OLB foster exploration where employees are encouraged to experiment, risk take and search for innovative solutions (Luu et al., 2017) thereby enhancing variance in their behaviors by promoting their autonomous thinking and acting and their endeavors to challenge their status quo. Accordingly, employees are inspired and empowered to reconfigure existing resources and search for new ones (Luu et al., 2019a). According to Li et al., (2015) this can be done through broadening existing knowledge base by searching for new organizational norms, routines, structures and 
systems, experimenting new technologies, business processes or markets. On the other hand, CLB promote exploitation where setting guidelines, monitoring goal achievement and taking corrective actions are demonstrated (Luu et al., 2017). Through CLB employees effectively utilize existing resources to improve their performance and diminish variance in their behaviors (Luu et al., 2019a). Li et al., (2015) advocated deepening existing knowledge base by using and refining existing knowledge, focusing on production and elaborating on existing beliefs and decisions.

Consequently, AL might be regarded as a continuum where OLB and CLB are pursued contextually. According to Luu et al., (2019a) the switch between OLB and CLB is dependent on situational and organizational contexts. As elucidated by Rosing et al., (2011) AL accounts for situational contingencies where interactions between leaders, subordinates and situations should match fitting temporal goals and tasks. Moreover, Luo et al., (2018) indicated that organizational stability and dynamism is accounted for when choosing between OLB (stable or restoring balance) and CLB (dynamic).

\section{IRFC, TL and AB}

Several studies of recognized the value of TL in promoting AL activities (Baskarada et al., 2016; Zheng et al., 2016; Baskarada et al., 2017; Li et al., 2018; Berraies and Abdine, 2019; Zuraik and Kelly, 2019) where Keller and Weiber (2015) explicated that transformational leaders are prone to have an ambidextrous mental schema due to their delineation of clear organizational vision and goals enabling them to manage contradicting organizational interests.

Although Kosasih et al., (2020) investigated the mediating effect of change readiness on the influence of ambidextrous organizations and authentic followership on innovative performance, their study neither accounted for the precise behaviors of ambidextrous leaders, but rather the organizational ambidexterity as an abstract concept, nor did for the predefined five dimensions of IRFC construct. However, the researchers postulate a moderating effect of $\mathrm{AB}$ on the relationship between TL and IRFC since we believe that ambidexterity strengthens such relation based on the 
documented value of $\mathrm{TL}$ in promoting $\mathrm{AB}$ activities. Accordingly the following hypothesis is formulated and its related sub-hypotheses;

$\mathbf{H}_{2}$ : Ambidextrous behaviors have a moderating effect on the relationship between transformational leadership and individual readiness for change within research population under investigation;

$\mathbf{H}_{2 \mathrm{a}}$ : Ambidextrous behaviors have a moderating effect on the relationship between idealized influence and valence and appropriateness within research population under investigation.

$\mathbf{H}_{2 \mathbf{b}}$ : Ambidextrous behaviors have a moderating effect on the relationship between idealized influence and personal benefits within research population under investigation.

$\mathbf{H}_{2 \mathbf{c}}$ : Ambidextrous behaviors have a moderating effect on the relationship between inspirational motivation and valence and appropriateness within research population under investigation.

$\mathbf{H}_{\text {2d: }}$ : Ambidextrous behaviors have a moderating effect on the relationship between inspirational motivation and personal benefits within research population under investigation.

$\mathbf{H}_{2 \mathrm{e}}$ : Ambidextrous behaviors have a moderating effect on the relationship between intellectual stimulation and valence and appropriateness within research population under investigation.

$\mathbf{H}_{2 \mathrm{f}}$ : Ambidextrous behaviors have a moderating effect on the relationship between intellectual stimulation and personal benefits within research population under investigation.

$\mathbf{H}_{2 \mathrm{~g}}$ : Ambidextrous behaviors have a moderating effect on the relationship between individualized consideration and valence and appropriateness within research population under investigation.

$\mathbf{H}_{2 \mathrm{~h}}$ : Ambidextrous behaviors have a moderating effect on the relationship between individualized consideration and personal benefits within research population under investigation.

The following figure (1) illustrates the research model; 

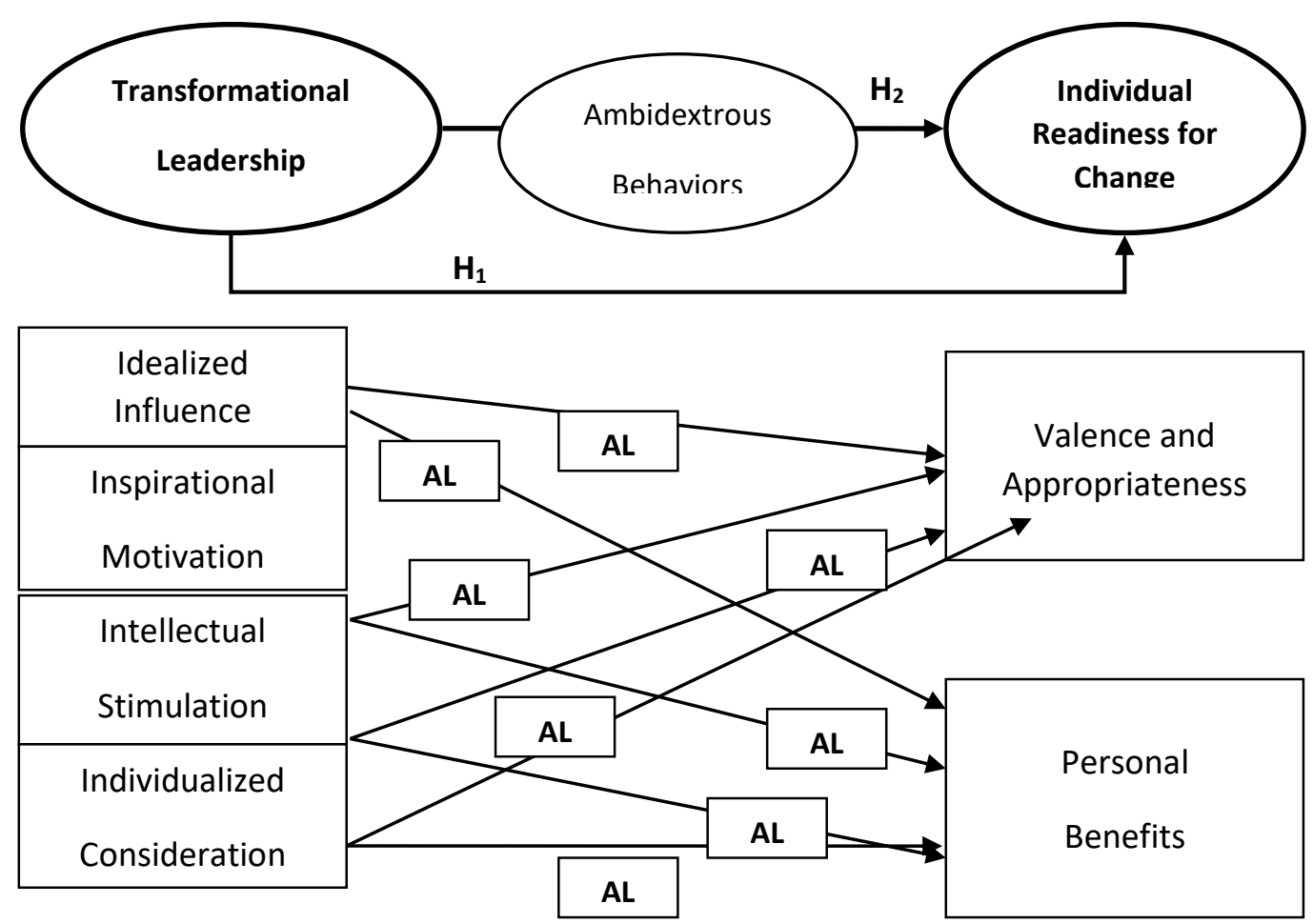

Figure (1)

Research model

\section{IRFC, TL and AB in Universities}

Universities, as an integral part of HES are in no isolation from the inevitable change phenomenon, however, realizing strategic change in universities is challenging. Stensaker et al., 2014; Smulowitz, 2015; O'Donnell, 2016 highlighted the difficulty of aligning different departments within a higher education unit to collaboratively march towards a common goal due to their inherent autonomous leadership and decision making where change processes might be impeded by the divergent interests of involved actors. Consequently, to initiate change in universities, faculty readiness to proposed changes is vital for reinforcing its execution where dimensions of IRFC must be investigated.

While the importance of leadership in various domains has been highlighted in the literature, effective leadership styles in the context of HES, Universities in particular, have not been well articulated in the leadership literature (Hassan et al., 2018; Barrett et al., 2019). The scant research found almost had a common premise of contrasting the impacts of transactional and transformational leaderships, on job satisfaction (Alonderiene and Majauskaite, 2016), employees motivation (Fazzi and Zamaro, 2016), organizational learning (Khalifa and Ayoubi, 2015), organizational 
commitment (Mwesigwa et al., 2020). Nevertheless, Ambidexterity was scarcely investigated in HES. Ripkey (2017) explored the organizational ambidextrous challenges faced by leaders in pursuing a university merger processes while Souza and Takahashi (2019) investigated the relationship between dynamic capabilities and organizational ambidexterity. Yet, both studies investigated ambidexterity in abstract and did not account for AL practices in their contexts.

\section{Research Methodology}

\section{Research population and sample}

Egyptian universities are challenged by fulfilling the HES aspirations to achieve a domestic, regional and international competitive advantage by attaining world standards of teaching processes and scientific research (NAQAAE, 2009). National Authority for Quality Assurance and Accreditation of Education issued in January 2009 its first blueprint for reforming and accrediting quality for Egyptian Universities emphasizing a culture of quality and continuous improvement where, subsequently, potential changes might be introduced to academic and/or non-academic processes.

The Egyptian HES includes 54 Universities (28 public and 26 private) granted full accreditation recognition by the Egyptian supreme council of Universities, hosting 128,181 faculty members for the year 2019/2020 (CAPMAS, 2020). Sample size was calculated using Thompson equation (Thompson, 2012) where 383 were indicated. However 500 surveys were distributed taking into account non response bias. 421 surveys were collected where only 400 were valid for statistical testing.

Due to the wide geographic dispersion of Egyptian Universities and insufficient research resources, Universities were limited to the greater Cairo area and chosen using the basket method to maintain data collection objectivity (Fisher, 1987). Accordingly, two mutually exclusive baskets for each category (public and private) were set and a random number from (19) was selected from each. This resulted in choosing (2) Universities from each category. The basket method was once more repeated to choose among common colleges between the four selected Universities resulting in choosing (1) common college. Surveys were proportionately and randomly distributed as shown in the following table; 
Proportionate distribution on research sample

\begin{tabular}{|c|c|c|c|c|}
\hline \multirow[b]{2}{*}{ Items } & \multicolumn{2}{|c|}{ Public Universities } & \multicolumn{2}{|c|}{ Private Universities } \\
\hline & $\begin{array}{l}\text { University } \\
\text { (A) }\end{array}$ & $\begin{array}{l}\text { University } \\
\text { (B) }\end{array}$ & $\begin{array}{l}\text { University } \\
\text { (C) }\end{array}$ & $\begin{array}{l}\text { University } \\
\text { (D) }\end{array}$ \\
\hline Number of faculty members* & 495 & 186 & 89 & 149 \\
\hline $\begin{array}{l}\text { Total number of faculty } \\
\text { members in chosen sample }\end{array}$ & 919 & 919 & 919 & 919 \\
\hline Percentage of distribution ${ }^{* * *}$ & $54 \%$ & $20 \%$ & $10 \%$ & $16 \%$ \\
\hline $\begin{array}{c}\text { Number of distributed } \\
\text { surveys }^{\#}\end{array}$ & 270 & 100 & 50 & 80 \\
\hline $\begin{array}{c}\text { Number of valid collected } \\
\text { surveys }\end{array}$ & 202 & 116 & 37 & 45 \\
\hline $\begin{array}{l}\text { Total number of valid } \\
\text { collected surveys }\end{array}$ & 400 & 400 & 400 & 400 \\
\hline $\begin{array}{c}\text { Percentage of valid collected } \\
\text { surveys }\end{array}$ & $50.5 \%$ & $29 \%$ & $9.25 \%$ & $11.25 \%$ \\
\hline
\end{tabular}

* According to CAPMAS (2020).

** sum of number of faculty members in chosen sample.

*** number of faculty members divided by total number of faculty members of chosen sample.

\# percentage of distribution of each university multiplied by number of surveys distributed (500).

\#\#\# number of valid collected surveys divided by their total number.

The following table represents the proliferation of research sample according their demographical characteristics; job title, type of employer, tenure, age group, and gender:

\section{Table (2)}

Demographical frequency distribution of research sample

\begin{tabular}{|c|c|c|c|c|}
\hline \multicolumn{5}{|c|}{ "Job Title" } \\
\hline$\#$ & Job Title & Frequency & percentage & Rank \\
\hline 1. & Professor & 35 & $8.75 \%$ & 4 \\
\hline 2. & Associate Professor & 54 & 13.5 & 3 \\
\hline 3. & Assistant Professor & 120 & 30 & 2 \\
\hline 4. & Teaching Assistant & 191 & 47.75 & 1 \\
\hline \multicolumn{5}{|c|}{ Total Type of Employer (University)" } \\
\hline$\#$ & Job Title & Frequency & percentage & Rank \\
\hline 1. & Public & 318 & $79.5 \%$ & 1 \\
\hline 2. & Private & 82 & 20.5 & 2 \\
\hline \multicolumn{5}{|c|}{ Total } \\
\hline
\end{tabular}


Table (2) Cont'd

\begin{tabular}{|c|c|c|c|c|}
\hline \multicolumn{5}{|c|}{ "Tenure" } \\
\hline \# & Job Title & Frequency & percentage & Rank \\
\hline 1. & Less than 5 years & 38 & $9.5 \%$ & 4 \\
\hline 2. & $5-9$ years & 64 & 16 & 3 \\
\hline 3. & $10-14$ years & 160 & 40 & 1 \\
\hline 4. & More than 15 years & 138 & 34.5 & 2 \\
\hline \multirow{2}{*}{\multicolumn{5}{|c|}{\begin{tabular}{l|} 
"Age group" \\
"
\end{tabular}}} \\
\hline & & & & \\
\hline \# & Job Title & Frequency & percentage & Rank \\
\hline 1. & $20-29$ years old & 36 & $9 \%$ & 4 \\
\hline 2. & $30-39$ years old & 192 & 48 & 1 \\
\hline 3. & $40-49$ year old & 12 & 30 & 2 \\
\hline 4. & More than 50 years old & 52 & 13 & 3 \\
\hline & Total & 400 & 100 & - \\
\hline \multicolumn{5}{|c|}{ "Gender } \\
\hline$\#$ & Job Title & Frequency & percentage & Rank \\
\hline 1. & Male & 212 & $53 \%$ & 1 \\
\hline 2. & Female & 188 & 47 & 2 \\
\hline \multicolumn{2}{|r|}{ Total } & 400 & 100 & - \\
\hline
\end{tabular}

According to table (2), logical conformance of research sample and its alignment to normal distribution might be included and the representation of research sample might be inferred.

\section{Research instrument and measures}

A self-report three sections survey (as shown in appendix I) structuring close-ended questions was administered covering multiple underlying items of key research variables. Close-ended questions provide fixed answer options which the respondent has to select alleviating statistical evaluation of responses; moreover, it can be answered anonymously, allowing respondents to provide honest answers from one's own point of view (Leyer and Moormann 2014). The Likert scale was used as a rating scale indicating the level of agreement on a scale from "5 strongly agree" to "1 strongly disagree". Hence, the objective of the survey was to capture the personal opinions of faculty members and non-academic staff. A set of 43 questions (in addition to 5 personal information questions for the proliferation of sample) was used drawn from the literature as follows:

IRFC (13 questions): assessed using the 30-item scale developed by Holt et al. (2007) and validated by the studies of Haffar et al., 2014; Allaoui and Benmoussa, 2020. Only two; valence and Appropriateness (10) and personal 
benefits (3) of the four behavioral components of IRFC were operationalized. A sample item measuring valence and appropriateness was "There are legitimate reasons for us to make this change". While a sample item measuring personal benefit was "My future in this job will be limited because of this change".

TL (20 questions): measured using employee ratings on the $20 \mathrm{TL}$ items from the Multifactor Leadership Questionnaire (MLQ) developed by Bass and Avolio (2000) and well validated in leadership literature (Berraies and Abidine, 2019; Zuraik and Kelly, 2019; Busari et al., 2020). A sample item measuring the leader's II (5) was "My leader goes beyond self-interest for the good of the group" while for IM (5) was "My leader expresses confidence that goals will be achieved." An item relating to the IS (5) was "My leader suggests new ways of looking at how to complete assignments" while for IC was "My leader considers me as having different needs, abilities, and aspirations from others".

$\mathrm{AB}$ (10 questions): assessed using the 14-item scale developed by Rosing et al. (2011) for OLB (5) and CLB (5) and validated by multiple studies (Zacher and Rosing, 2015; Zacher et al., 2016; Abuzid, 2019). Sample item for OLB was "My leader allows different ways of accomplishing a task" while for CLB was "My leader monitors and controls goal attainment".

\section{Analysis and Results}

Cronbach's alpha was used to test the reliability and validity of the survey, where $\alpha$ closer to 1 refers to excellent reliability and $<0.7$ is questionable. As shown in table (3), $\alpha$ was between (0.84) and (0.916) which indicates that the designed survey accurately measured IRFC, TL and AB. Internal consistency was calculated using Pearson correlation coefficient to measure the relationship between each statement and the overall degree of consistency with the total of its dimension. Correlation coefficients for TL were between $(0.576,0.843)$, between $(0.665,0.724)$ for $\mathrm{AB}$ and $(0.605$, 0.821 ) for IRFC indicating moderate to strong relationships with regard to the consistency of the designed survey.

Table (4) demonstrates the descriptive statistics (mean, standard deviation and coefficient of variation) of research data, conducted with an emphasis 
on demonstrating; the tendencies of analyses, quality of collected data, and efficiency of data preparation processes. Pearson correlation coefficient (r) was used to test the direction and strength of the relationship between TL and IRFC. As shown in table (5) positive (r) of 0.775 was detected at a $<$ 0.01 significance level, indicating a significant positive relationship between TL and IRFC. Thus, $\mathrm{H}_{1}$ was accepted. Accordingly, linear regression analysis was used to measure the effect of TL on IRFC as shown in table (6) and effects of TL dimensions on IRFC are illustrated in table (7).

Table (3)

Reliability and Validity of IRFC, TL and AB dimensions

\begin{tabular}{|c|c|c|c|c|}
\hline ser. & Dimensions & \multicolumn{1}{c}{ Reliability } & Validity & $\mathrm{r}$ \\
\hline \hline $\mathrm{x} 1$ & Idealized Influence & 0.802 & 0.895 & $0.664^{* *}$ \\
\hline $\mathrm{x} 2$ & Inspirational Motivation & 0.798 & 0.893 & $0.576^{*}$ \\
\hline $\mathrm{x} 3$ & Intellectual Stimulation & 0.819 & 0.819 & $0.777^{* *}$ \\
\hline Total x & $\begin{array}{c}\text { Individualized } \\
\text { Consideration }\end{array}$ & 0.776 & 0.880 & $0.843^{* *}$ \\
\hline $\mathrm{m} 1$ & $\begin{array}{c}\text { Transformational } \\
\text { Leadership }\end{array}$ & 0.819 & 0.904 & - \\
\hline $\mathrm{m} 2$ & $\begin{array}{c}\text { Opening Leadership } \\
\text { Behaviors }\end{array}$ & 0.857 & 0.925 & $0.724^{* *}$ \\
\hline Total m & $\begin{array}{c}\text { Ambingaviors } \\
\text { Behaviors }\end{array}$ & 0.828 & 0.909 & $0.665^{* *}$ \\
\hline \hline $\mathrm{y} 1$ & $\begin{array}{c}\text { Valence and } \\
\text { Appropriateness }\end{array}$ & 0.806 & 0.897 & $0.821^{* *}$ \\
\hline $\mathrm{y} 2$ & Personal benefits & 0.791 & 0.889 & $0.605^{* *}$ \\
\hline Total y & $\begin{array}{c}\text { Individual Readiness for } \\
\text { change }\end{array}$ & 0.831 & 0.911 & - \\
\hline \hline Total sample: IRFC, TL and AB & 0.840 & 0.916 & - \\
\hline
\end{tabular}

** Significant level (0.01), * Significant level (0.05)

$\mathrm{R}^{2}$ determines the proportion of variance in the dependent variable that can be explained by the independent variable. It shows how well the data fit the regression model (goodness of fit). As shown in table (6) we found that TL explains $60.1 \%$ of the total variation in IRFC and the rest were due to random error in the equation, or perhaps due to other independent variables that were not included in the regression model. 
Table (4)

$\mathrm{TL}, \mathrm{AB}$ and IRFC descriptive Statistics and correlations

\begin{tabular}{|c|c|c|c|c|}
\hline Items & Mean & Std. & c.v. & Rank \\
\hline Idealized Influence & 2.83 & 0.90 & 31.80 & 4 \\
\hline Inspirational Motivation & 4.01 & 0.94 & 23.44 & 2 \\
\hline Intellectual Stimulation & 3.30 & 0.91 & 27.58 & 3 \\
\hline Individualized Consideration & 4.44 & .990 & 22.30 & 1 \\
\hline $\begin{array}{c}\text { Transformational Leadership } \\
\text { Average }\end{array}$ & 3.66 & 0.65 & 17.76 & - \\
\hline Opening Leadership Behaviors & 3.09 & 0.70 & 22.65 & 2 \\
\hline Closing leadership Behaviors & 4.38 & 0.59 & 13.47 & 1 \\
\hline $\begin{array}{c}\text { Ambidextrous Behaviors } \\
\text { Average }\end{array}$ & 3.64 & 0.51 & 14.01 & - \\
\hline Valence and Appropriateness & 3.67 & 0.43 & 11.72 & 1 \\
\hline Personal benefits & 2.81 & 0.93 & 33.10 & 2 \\
\hline $\begin{array}{l}\text { Individual Readiness for change } \\
\text { Average }\end{array}$ & 3.29 & 0.56 & 17.02 & - \\
\hline
\end{tabular}

Rank: (1) for form the smallest c.v. and (2) to the largest c.v.

Table (5)

Pearson correlation between TL and IRFC

\begin{tabular}{|l|l|l|}
\hline Sig. & $\mathrm{r}$ & Dimension \\
\hline $0.001 * *$ & 0.775 & Leadership $\mathrm{x}$ and Individual Readiness For Change y \\
\hline
\end{tabular}

** Significance level 0.01

Table (6)

Effect of TL on IRFC using Liner Regression

\begin{tabular}{|c|c|c|c|c|c|c|}
\hline \multirow[t]{2}{*}{$\mathrm{R}^{2}$} & \multicolumn{2}{|c|}{ F. test } & \multicolumn{2}{|c|}{ t. test } & \multirow[b]{2}{*}{$\beta$} & \multirow{2}{*}{ Independent variables } \\
\hline & Sig. & Value & Sig. & Value & & \\
\hline \multirow[b]{2}{*}{$60.1 \%$} & \multirow[b]{2}{*}{ 001.** } & \multirow[b]{2}{*}{651.342} & $0.01 * *$ & 5.556 & 0.563 & constant \\
\hline & & & $0.01 * *$ & 25.521 & 0.775 & Transformational \\
\hline
\end{tabular}

** Significance level 0.01

To test the fit of the regression model as a whole, F-test was used indicating a value of 651.342 at a level of significance 0.01 which refers to the quality of the regression model impact on IRFC. T-test was used to detect the significance of TL impact on IRFC. We found that TL has a significant effect on IRFC as the value of $t$ was 25.521 at a significant level $<0.01$ and 
a correlation coefficient $\beta$ of 0.775 . The form of the fitted regression Equation $(\mathrm{Y}=\beta 0+\beta 1 \mathrm{x})$ can be expressed as follows;

Individual Readiness for Change $=0.563+0.775$ Transformational

Leadership.

As shown in table (7), II explained $23.7 \%$ of the total variation in VA and $19.4 \%$ in PB. F-test value with VA was 134.505 and 104.363 with PB referring to a quality impact of II. Moreover, II had significant effects on VA and $\mathrm{PB}$ where $\mathrm{t}$ values of 11.598 and 10.216 were computed. Consequently, II regression equations are; Valence and Appropriateness $=1.600+0.487$ Idealized Influence, and "Personal Benefits $=2.050+0.441$ Idealized Influence. IM was found to explain $30.9 \%$ of the total variation of VA and $23.8 \%$ of the total variation of PB. A quality impact of IM on VA and PB was indicated by F-test values of 193.358 and 135.456 respectively. A significant effect of IM was found by conducting t-test on VA and PB with values of 13.905 and 11.639 respectively.

Regression equations for IM are; "Valence and Appropriateness" $=1.088+$ 0.556 "Inspirational motivation" and "Personal Benefits" $=1.721+0.488$ "Inspirational motivation". Where IS explained a total variation of $33.5 \%$ in VA and $26.4 \%$ in PB. Quality significance was reported by F-test value of 218.453 on VA and 155.106 on PB. IS had a significant effect on VA and PB according to t-test values of 14.780 and12.454 respectively. Regression Equations for IS are "Valence and Appropriateness" $=1.037+0.579$ "Intellectual Stimulation" and "Personal Benefits" $=1.672+0.514$ "Intellectual Stimulation". IC explained $48.5 \%$ of the total variation in VA and $46 \%$ in PB. Quality impacts of IC were recorded by F-test values of 407.184 on VA and 368.524 on PB. Significant effects on VA and PB were found according to t-test values of 20.179 on VA and 19.197 on PB. Regression equations for IC are "Valence and Appropriateness" $=0.654+$ 0.696 "Individualized Consideration" and "Personal Benefits" $=1.156+$ 0.678 "Individualized Consideration". 


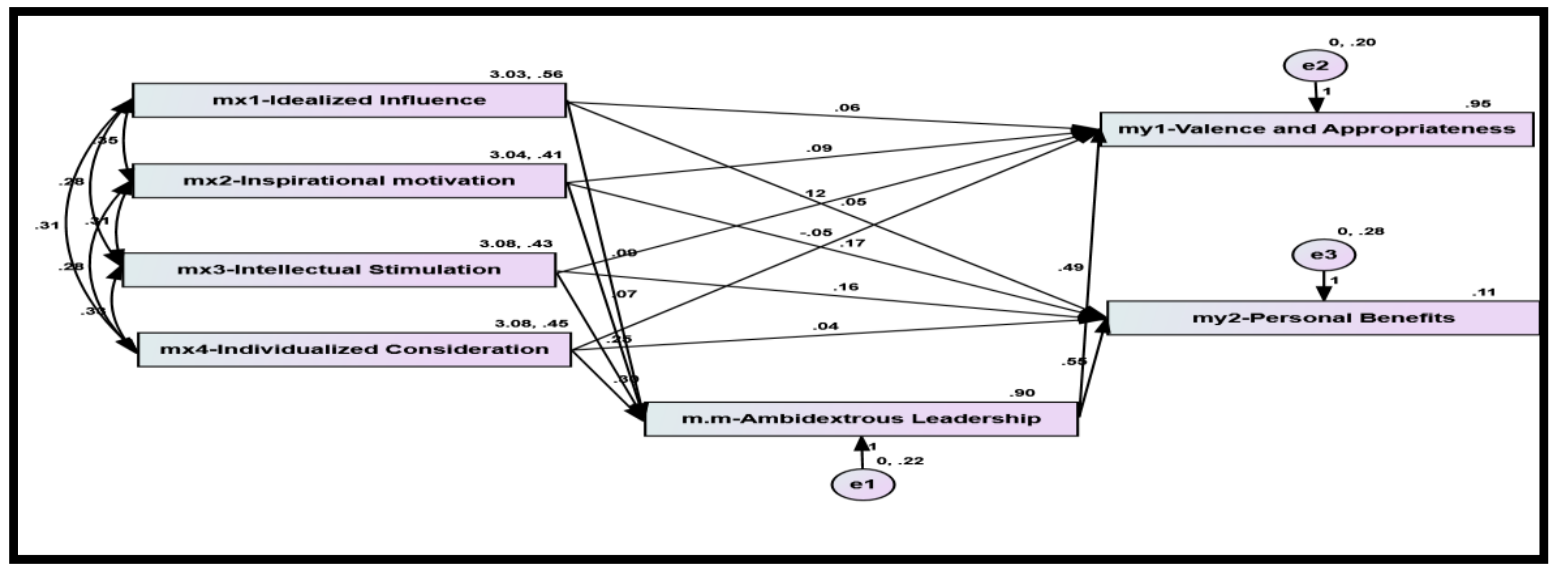

Figure (2)

Path analysis values

Table (8)

Coefficients estimates of the structural model of $\mathrm{AB}$ moderating effect on the relationship between TL and IRFC

\begin{tabular}{|c|c|c|c|c|c|c|c|}
\hline \multicolumn{3}{|r|}{ Path } & $\begin{array}{c}\text { estimat } \\
\text { es }\end{array}$ & S.E. & C.R. & $\begin{array}{c}\mathrm{P}- \\
\text { Value }\end{array}$ & Sig. \\
\hline \multirow{4}{*}{$\begin{array}{l}\text { Ambidextrou } \\
\text { s Behaviors }\end{array}$} & $\square$ & Idealized Influence & 0.088 & 0.046 & 1.91 & 0.056 & Insig. \\
\hline & $\square$ & $\begin{array}{l}\text { Inspirational } \\
\text { Motivation }\end{array}$ & 0.069 & 0.063 & 1.094 & 0.274 & Sig. \\
\hline & $\square$ & Intellectual Stimulation & 0.246 & 0.059 & 4.169 & $\begin{array}{c}0.001 * \\
*\end{array}$ & Sig. \\
\hline & $\square$ & $\begin{array}{l}\text { Individualized } \\
\text { Consideration }\end{array}$ & 0.299 & 0.054 & 5.573 & $\begin{array}{c}0.001 * \\
*\end{array}$ & Sig. \\
\hline \multirow{5}{*}{$\begin{array}{c}\text { Valence and } \\
\text { Appropriatene } \\
\text { ss }\end{array}$} & $\square$ & Idealized Influence & 0.057 & 0.044 & 1.289 & 0.197 & Insig. \\
\hline & $\square$ & $\begin{array}{c}\text { Inspirational } \\
\text { Motivation }\end{array}$ & 0.09 & 0.06 & 1.506 & 0.132 & Insig. \\
\hline & $\square$ & Intellectual Stimulation & 0.121 & 0.057 & 2.114 & $0.034 *$ & Sig. \\
\hline & $\square$ & $\begin{array}{l}\text { Individualized } \\
\text { Consideration }\end{array}$ & -0.047 & 0.053 & -0.888 & 0.375 & Insig. \\
\hline & $\square$ & $\begin{array}{c}\text { Ambidextrous } \\
\text { Behaviors }\end{array}$ & 0.49 & 0.046 & 10.706 & $\begin{array}{c}0.001 * \\
*\end{array}$ & Sig. \\
\hline \multirow{5}{*}{$\begin{array}{l}\text { Personal } \\
\text { Benefits }\end{array}$} & $\square$ & Idealized Influence & 0.047 & 0.052 & 0.907 & 0.365 & Insig. \\
\hline & $\square$ & $\begin{array}{c}\text { Inspirational } \\
\text { Motivation }\end{array}$ & 0.171 & 0.071 & 2.412 & $0.016^{*}$ & Sig. \\
\hline & $\square$ & Intellectual Stimulation & 0.16 & 0.068 & 2.368 & $0.018^{*}$ & Sig. \\
\hline & $\square$ & $\begin{array}{l}\text { Individualized } \\
\text { Consideration }\end{array}$ & 0.043 & 0.062 & 0.692 & 0.489 & Insig. \\
\hline & $\square$ & $\begin{array}{c}\text { Ambidextrous } \\
\text { Behaviors }\end{array}$ & 0.55 & 0.054 & 10.209 & $\begin{array}{c}0.001 * \\
*\end{array}$ & Sig. \\
\hline
\end{tabular}

**Significant at the (0.01) level, *Significant at the (0.05) level 
Moreover, An Independent t-test was used to investigate the statistical significant difference between public and private Universities regarding the impact of $\mathrm{TL}$ and $\mathrm{AB}$ on IRFC of which $<0.05$ indicates significant difference and $>0.05$ indicates insignificant difference.

Table (9)

Total, direct, and Indirect Effects of the structural model for interpreting relationships

\begin{tabular}{|c|c|c|c|c|c|c|}
\hline Effects & Variables & $\begin{array}{c}\text { Idealize } \\
\mathrm{d} \\
\text { Influenc } \\
\mathrm{e} \\
\end{array}$ & $\begin{array}{c}\text { Inspiration } \\
\text { al } \\
\text { Motivation }\end{array}$ & $\begin{array}{c}\text { Intellectua } \\
1 \\
\text { Stimulatio } \\
\mathrm{n}\end{array}$ & $\begin{array}{c}\text { Individualize } \\
\mathrm{d} \\
\text { Consideratio } \\
\mathrm{n}\end{array}$ & $\mathrm{AL}$ \\
\hline \multirow{3}{*}{$\begin{array}{l}\text { Total } \\
\text { Effects }\end{array}$} & $\begin{array}{c}\text { Ambidextrous } \\
\text { Behaviors }\end{array}$ & 0.088 & 0.069 & 0.246 & 0.299 & - \\
\hline & $\begin{array}{c}\text { Valence and } \\
\text { Appropriatene } \\
\text { ss }\end{array}$ & 0.100 & 0.124 & 0.242 & 0.100 & $\begin{array}{c}0.49 \\
0\end{array}$ \\
\hline & $\begin{array}{l}\text { Personal } \\
\text { Benefits }\end{array}$ & 0.096 & 0.209 & 0.296 & 0.208 & $\begin{array}{c}0.55 \\
0\end{array}$ \\
\hline \multirow{3}{*}{$\begin{array}{l}\text { Direct } \\
\text { Effects }\end{array}$} & $\begin{array}{c}\text { Ambidextrous } \\
\text { Behaviors }\end{array}$ & 0.088 & 0.069 & 0.246 & 0.299 & - \\
\hline & $\begin{array}{c}\text { Valence and } \\
\text { Appropriatene } \\
\text { ss }\end{array}$ & 0.057 & 0.090 & 0.121 & 0.047 & $\begin{array}{c}0.49 \\
0\end{array}$ \\
\hline & $\begin{array}{l}\text { Personal } \\
\text { Benefits }\end{array}$ & 0.047 & 0.171 & 0.160 & 0.043 & $\begin{array}{c}0.55 \\
0\end{array}$ \\
\hline \multirow{3}{*}{$\begin{array}{c}\text { Indirec } \\
\text { t } \\
\text { Effects }\end{array}$} & $\begin{array}{c}\text { Ambidextrous } \\
\text { Behaviors }\end{array}$ & - & - & - & - & - \\
\hline & $\begin{array}{c}\text { Valence and } \\
\text { Appropriatene } \\
\text { ss }\end{array}$ & 0.043 & 0.034 & 0.121 & 0.147 & - \\
\hline & $\begin{array}{l}\text { Personal } \\
\text { Benefits }\end{array}$ & 0.049 & 0.038 & 0.135 & 0.165 & - \\
\hline
\end{tabular}

Table (10)

Test the difference between Public and Private Universities for IRFC, TL and $\mathrm{AB}$

\begin{tabular}{|c|c|c|c|c|c|c|c|}
\hline Variable & Sample & $\mathrm{N}$ & Mean & Std. & $\mathrm{t}$ & $\begin{array}{c}\mathrm{P}- \\
\text { value }\end{array}$ & Result \\
\hline \multirow{2}{*}{$\begin{array}{c}\text { Transformational } \\
\text { Leadership }\end{array}$} & Public & 353 & 3.12 & 0.53 & \multirow{2}{*}{1.221} & \multirow{2}{*}{0.22} & \multirow{2}{*}{ Insignificant } \\
\hline & Private & 82 & 3.04 & 0.59 & & & \\
\hline \multirow{2}{*}{$\begin{array}{l}\text { Individual } \\
\text { Readiness } \\
\text { for Change }\end{array}$} & Public & 353 & 3.11 & 0.60 & \multirow{2}{*}{0.749} & \multirow{2}{*}{0.45} & \multirow{2}{*}{ Insignificant } \\
\hline & Private & 82 & 3.05 & 0.69 & & & \\
\hline
\end{tabular}




\begin{tabular}{|c|c|c|c|c|c|c|c|}
\hline \multirow{2}{*}{$\begin{array}{c}\text { Ambidextrous } \\
\text { Behaviors }\end{array}$} & Public & 353 & 3.13 & 0.59 & \multirow{2}{*}{2.016} & \multirow{2}{*}{$0.04 *$} & Significant. \\
\cline { 2 - 5 } & Private & 82 & 3.28 & 0.63 & & & \\
\hline
\end{tabular}

*Significance level (0.05)

According to the analyses shown in table (10), there is a significant difference between public and private Universities for $A B$ whose $t$ value was 2.016, P-value $<0.05$ in favor of private Universities whose mean was 3.28 and 3.13 for public Universities. However, there was no significant difference between public and private Universities with regard to TL whose $\mathrm{P}$-values were $>0.05$. Moreover, there was no significant difference between public or private Universities' IRFC whose P-value was $>0.05$.

\section{Conclusion}

Dynamic changes in business environments challenged organizations to embark on initiatives or utilize varying mechanisms aiming at improving their performance and achieving competitive advantages. Effective implementation of such changes is a foremost leadership responsibility where individuals are of pivotal importance based on their roles in affecting changes accordingly their readiness to embark on change is a matter of crucial consequence.

Multiple leadership styles were documented in the literature where different contingencies influence chosen style to embark on changes. TL was postulated as more appropriate to effectuate changes; however, TL has been criticized for its insufficient specification of situational variables neglecting boundary conditions which might mitigate its effect where a balance between preservation and innovation must be maintained effectively.

Consequently the purpose of our study was to examine the impact of the TL behaviors on IRFC in particular two of the latter constituents (valence and appropriateness, and personal benefits). Moreover, the researchers postulated a moderating effect of $\mathrm{AB}$ on the relationship between TL and IRFC based on the documented value of TL in promoting AB. Since Egyptian Universities are in no isolation from the inevitable change phenomenon where realizing strategic change in is highly demanding, the researches empirically investigated the research model the context of one common college in two public and private Universities. 
Research hypotheses were accepted where data analyses concluded that TL had a positive impact on IRFC moderated by AB. TL positively affected IRFC where its' dimensions showed greater impacts on VA than on PB where IC had the most influential impact on both of IRFC constituents followed by IS, IM and II respectively. IC had also the most influential impact on AB followed by IS, II and IM respectively while AB had more influential impact on PB than on VA.

It was found that II had a direct insignificant relationship on VA and an indirect insignificant relationship on PB. IM had a direct insignificant relationship on VA and a direct significant relationship on PB. While IS had a direct significant relationship with VA and PB and IC had indirect insignificant relationships on VA and PB. II and IM had direct insignificant relationship with $\mathrm{AB}$ while IS and IC had significant direct relationships with $\mathrm{AB}$. And $\mathrm{AB}$ had direct significant relationships with VA and $\mathrm{PB}$.

Moreover, an insignificant difference was concluded between public or private Universities with regard to TL and IRFC while a significant difference was concluded in favor of private Universities for AB.

\section{Recommendations}

In light of research conclusions, the researchers recommend that following studies should take into considerations descriptive aspects (which we were unable to investigate as an un-integral part of the current research but would be of esteemed value) of the occurring changes, such as type of change (e.g. revolutionary vs. evolutionary), duration of change, time stage of change, and so forth to gain a complete overview about main effects of the changes' inherent characteristic on functional or dysfunctional reactions toward a change. More specific, future studies should, for example, explicitly test the moderation effect of the type of change on the relationship between transformational leadership and employees' readiness for change.

Another aspect for future research might be the impact of organizational culture on the dynamics of our tested research model. Organizational culture is a determinant success factor for any improvement intiative and accompanying organizational changes, where a supporting culture enhances individual job commitment and emphasizes goal oriented performance.

In addition, a comparative inspection for the impacts of multiple styles on the IRFC in the Egyptian HEIs would bring insightful perspectives of how leaders may set practical agendas to elevate their subordinate, not only 
readiness for change but also, performance and motivation to embark on work related improvement changes.

Moreover, though the structure of data is already complex, we were not able to validate our results by a longitudinal design where extended investigation to more Universities and other Egyptian HEIs would provide thorough insights to individuals causal directions, even though grounded theoretically, cannot be interpreted with full certainty. Besides solving the problems of causal validity, longitudinal studies would heavily expand our knowledge about the effectiveness of leadership behaviors and attitudes in different time stages of a change.

Also, it would be highly interesting under which circumstances the detected moderating effect of AL behaviors to change is more or less important. Thus, future research should pick up the findings of this study and move a step further by investigating three way interactions between "providing a appropriate model," leaders' own behaviors toward change and, for example employees' self efficacy beliefs.

Finally, the study's used empirical methodology is only one possible way of measurement. Even though quantitative research methods bear the advantage of greater generalizability and, due to advanced statistical methods, validity of results, qualitative data capturing might allow for more detailed analysis of single relationships and interactions between leaders' behaviors and followers' reactions. Thus, future studies should complement the existing results by conducting single case studies, for example, by observation and/or interviewing leaders and their team members confronted with a major change initiative. 


\section{References}

1. Abrell-Vogel, C. \& Jens Rowold J. (2019). Leaders' commitment to change and their effectiveness in change - a multilevel investigation. Journal of Organizational Change Management, 27(6), 900-921.

2. Abuzid, H. (2019). Relationship between ambidextrous behaviors, and entrepreneurial orientation mediated the role of organizational social capital and organizational determinants. Scientific Journal for Economic and Commerce, 559-600. Retrieved from

https://jsec.journals.ekb.eg/article_38810_0c68cb3211de63334573a4cc8b1 aaae3.pdf. (Arabic study).

3. Abuzid, H. \& Abbas, M. (2016). Role of self-efficacy beliefs and its relationship with emotional intelligence to developing leadership. IJBER, 14(3), 1975-1989.

4. Adil, M. (2016). Impact of change readiness on commitment to technological change, focal, and discretionary behaviors: Evidence from the manufacturing sector of Karachi. Journal of Organizational Change Management, 29(2), 222-241.

5. Al-Haddad, S. \& Kotnour, T. (2015). Integrating the organizational change literature: a model for successful change. Journal of Organizational Change Management, 28(2), 234-262.

6. Al-Hussami, M., Hamad, S., Darawad, M. \& Maharmeh, M. (2017). The effects of leadership competencies and quality of work: The effects of leadership competencies and quality of work on the perceived readiness for organizational change among nurse managers. Leadership in Health Services, 30(4), 443-456.

7. Al-Hussami M., Hammad, S. \& Alsoleihat, F. (2018). The influence of leadership behavior, organizational commitment, organizational support, subjective career success on organizational readiness for change in healthcare organizations. Leadership in Health Services, 31(4), 354-370.

8. Albliwi, S., Antony, J., Lim, S. \& Wiele, T. (2014). Critical failure factors of Lean Six Sigma: a systematic literature review. International Journal of Quality \& Reliability Management, 31(9), 1012-1030.

9. Allaoui, A. \& Benmoussa, R. (2020). Employees' attitudes toward change with Lean Higher Education in Moroccan public universities. Journal of Organizational Change Management, 33(2), 253-288.

10.Alonderiene, R. \& Majauskaite, M. (2016). Leadership style and job satisfaction in higher education institutions. International Journal of Educational Management, 30(1), 140-164. 
11.Antony, J. (2014). Readiness factor for the Lean Six Sigma journey in the higher education sector. International Journal of Productivity and Performance Management, 63(2), 257-264.

12.Antony, J., Krishan, N., Cullen, D. \& Kumar, M. (2012). Lean Six Sigma for higher education institutions (HEIs): Challenges, barriers, success factors, tools/techniques. International Journal of Productivity and Performance Management, 61(8), 940-948.

13.Appelbaum, A., Degbe, M., MacDonald, O. \& Nguyen-Quang, T. (2015a). Organizational outcomes of leadership style and resistance to change (Part One). Industrial and Training, 47(2), 73-80.

14.Appelbaum, A., Degbe, M., MacDonald, O. \& Nguyen-Quang, T. (2015b). Organizational outcomes of leadership style and resistance to change (Part Two). Industrial and Training, 47(3), 135-144.

15.Armenakis, A., Harris, S., \& Mossholder, K. (1993). Creating readiness for organizational change. Human Relations, 46, 681-703.

16. Armenakis, A. \& Harris, S. (2002). Crafting a change message to create transformational readiness. Journal of Organizational Change Management, 15(2), 169-183.

17.Avolio, B., Walumbwa, F. \& Weber, T. (2009). Leadership: current theories, research, and future directions. Annual Review of Psychology, 60(1), 421-449.

18.Barrett, P., Gaskins, J. \& Haug, J. (2019). Higher education under fire: implementing and assessing a culture change for sustainment. Journal of Organizational Change Management, 32(1), 164-180.

19.Baskarada, S., Watson, J. \& Cromarty, J. (2016). Leadership and organizational ambidexterity. Journal of Management Development, 35(6), 778-788.

20.Baskarada, S., Watson, J. \& Cromarty, J. (2017). Balancing transactional and transformational leadership. International Journal of Organizational Analysis, 25(3), 506-515.

21.Bass, B. (1985). Leadership and Performance beyond Expectation. New York, United States of America: Free Press.

22.Bayraktar, S. \& Jimenez, A. (2020). Self-efficacy as a resource: a moderated mediation model of transformational leadership, extent of change and reactions to change. Journal of Organizational Change Management, 33(2), 301-317.

23.Berraies, S. \& Abidine, S. (2019). Do leadership styles promote ambidextrous innovation? Case of knowledge-intensive firms. Journal of Knowledge Management, 23(5), 836-859.

24.Boehm, S., Dwertmann, D., Bruch, H. \& Shamir, B. (2015). The missing link? Investigating organizational identity strength and transformational 
leadership climate as mechanisms that connect CEO charisma with firm performance. Leadership Quarterly, 26(2), 156-171.

25.Bonesso, S., Gerli, F. \& Scapolan, A. (2014). The individual side of ambidexterity: do individuals' perceptions match actual behaviors in reconciling the exploration and exploitation trade-off?. European Management Journal, 32(3), 392-405.

26.Burawat, P. (2019). The relationships among transformational leadership, sustainable leadership, lean manufacturing and sustainability performance in Thai SMEs manufacturing industry. International Journal of Quality \& Reliability Management, 36(6), 1014-1036.

27.Busari, A., Khan, S., Abdullah. S. \& Mughal, Y. (2020). Transformational leadership style, followership, and factors of employees' reactions towards organizational change. Journal of Asia Business Studies, 14(2), 181-209.

28.CAPMAS (2020). "Annual bulletin of students enrolled-teaching staff higher education 2019/2020", Central Agency for Public Mobilization and Statistics, October 2020, pp. 1-223.

29.Costello, J \& Arghode, V. (2020). Exploring member readiness for change in manufacturing industries using phenomenology. Management Research Review, 43(7), 847-861.

30.Douglas, J., Muturi, D., Douglas, A. \& Ochieng, J. (2017). The role of organisational climate in readiness for change to Lean Six Sigma. The TQM Journal, 29(5), 666-676.

31.Fazzi, G. \& Zamaro, N. (2016). Exploring the interplay between leadership styles and PSM in two organisational settings. International Journal of Manpower, 37(5), 859-877.

32.Fisher, S. (1987). A comparison of the basket method and stratified random sampling for contract change order negotiations (Master's thesis, Naval Postgraduate School, Monterey, California). Retrieved from https://guides.library.uq.edu.au/referencing/apa6/thesis.

33.Green, A., Albanese, B., Cafri, G. \& Aarons, G. (2014). Leadership, organizational climate, and working alliance in a children's mental health service system. Community Mental Health Journal, 50(7), 771-777.

34.Gurumurthy, A., Mazumdar, P. \& Muthusubramanian, S. (2013). Graph theoretic approach for analysing the readiness of an organisation for adapting lean thinking: A case study. International Journal of Organizational Analysis, 21(3), 396-427.

35.Haffar, M., Al-Karaghouli, W. \& Ghoneim, A. (2014). An empirical investigation of the influence of organizational culture on individual readiness for change in Syrian manufacturing organizations. Journal of Organizational Change Management, 27(1), 5-22. 
36.Haque, M., TitiAmayah, A. \& Liu, L. (2016). The role of vision in organizational readiness for change and growth. Leadership \& Organization Development Journal, 37(7), 983-999.

37.Hassan, A., Gallear, D. \& Sivarajah, U. (2018). Critical factors affecting leadership: a higher education context. Transforming Government: People, Process and Policy, 12(1), 110-130.

38.Hemme, F., Bowers, M. \& Todd, J. (2018). Change readiness as fluid trajectories: a longitudinal multiple-case study. Journal of Organizational Change Management, 31(5), 1153-1175.

39.Holt, D., Armenakis, A., Harris, S. \& Field, H. (2007). Toward a comprehensive definition of readiness for change: A review of research and instrumentation. Research in Organizational Change and Development, 16, 289-336.

40.Jansen, J., Van Den Bosch, F. \& Volberda, H. (2006). Exploratory innovation, exploitative innovation, and performance: effects of organizational antecedents and environmental moderators. Management Science, 52(11), 1661-1674.

41.Jansen, J., Vera, D. \& Crossan, M. (2009). Strategic leadership for exploration and exploitation: the moderating role of environmental dynamism. The Leadership Quarterly, 20(1), 5-18.

42.Katsaros, K., Tsirikas, A. \& Kosta, G. (2020). The impact of leadership on firm financial performance: the mediating role of employees' readiness to change. Leadership \& Organization Development Journal, 41(3), 333347.

43.Keller, T. \& Weibler, J. (2015). What it takes and costs to be an ambidextrous manager: linking leadership and cognitive strain to balancing exploration and exploitation. Journal of Leadership \& Organizational Studies, 22(1), 54-71.

44.Khalifa, B. \& Ayoubi, R. (2015). Leadership styles at Syrian higher education: What matters for organizational learning at public and private universities?. International Journal of Educational Management, 29(4), 477-491.

45.Kosasih, K., Wibowob, W. \& Saparuddinb, S. (2020). The influence of ambidextrous organization and authentic followership on innovative performance: The mediating role of change readiness. Management Science Letters, 10, 1513-1520.

46.Lehman, W., Greener, J. \& Simpson, D. (2002). Assessing organizational readiness for change. Journal of Substance Abuse Treatment, 22(4), 197-209.

47.Leyer, M. \& Moormann, J. (2014). How lean are financial service companies really? Empirical evidence from a large scale study in Germany. 
International Journal of Operations \& Production Management, 34(11), 1366-1388.

48.Li, C., Zhao, H. \& Begley, T. (2015). Transformational leadership dimensions and employee creativity in China: a cross-level analysis. Journal of Business Research, 68(6), 1149-1156.

49.Li, D., Lin, J., Cui, W. \& Qian, Y. (2018). The trade-off between knowledge exploration and exploitation in technological innovation. Journal of Knowledge Management, 22(4), 781-801.

50.Loh, K., Yusof, S. 7 Lau, D. (2019). Blue ocean leadership in lean sustainability. International Journal of Lean Six Sigma, 10(1), 275-294

51.Luo, B., Zheng, S., Ji, H. \& Liang, L. (2018). Ambidextrous leadership and TMT-member ambidextrous behavior: the role of TMT behavioral integration and TMT risk propensity. The International Journal of Human Resource Management, 29(2), 338-359.

52.Luu, T. (2017). Ambidextrous leadership, entrepreneurial orientation, and operational performance Organizational social capital as a moderator. Leadership \& Organization Development Journal, 38(2), 229-253.

53.Luu, T., Le, V., Masli, E. \& Rajendran, D. (2019a). Corporate social responsibility, ambidextrous leadership, and service excellence. Marketing Intelligence \& Planning, 37(5), 580-594.

54.Luu, T., Dinh, K. \& Qian, D. (2019b). Ambidextrous leadership, entrepreneurial orientation and job crafting. European Business Review, 31(2), 260-282.

55.Matzler, K., Bauer, F. \& Mooradian, T. (2015). Self-esteem and transformational leadership. Journal of Managerial Psychology, 30(7), 815831.

56.Mohammed, K., Othman, J. \& Silva, J. (2012). Social demographic factors that influence transformational leadership styles among top management in selected organizations in malaysia. Asian Social Science, 8(13), 51-58.

57.Mueller, F., Jenny, G. and Bauer, G. (2012). Individual and organizational health-oriented readiness for change: Conceptualization and validation of a measure within a large-scale comprehensive stress management intervention. International Journal of Workplace Health Management, 5(3), 220-236.

58.Munir, F., Nielsen, K., Garde, A., Albertsen, K. \& Carneiro, I. (2012). Mediating the effects of work- life conflict between transformational leadership and health-care workers' job satisfaction and psychological wellbeing. Journal of Nursing Management, 20(4), 512-521. 
59.Mwesigwa, R., Tusiime, I. \& Ssekiziyivu, B. (2020). Leadership styles, job satisfaction and organizational commitment among academic staff in public universities. Journal of Management Development, 39(2), 253-268. 60.NAQQAAE (2009), National Authority for Quality Assurance and Accreditation of Education publishing. Retrieved from: http://naqaae.eg/?page id=1237.

61.Nogueira, D., Sousa P., \& Moreira, M. (2018). The relationship between leadership style and the success of Lean management implementation. Leadership \& Organization Development Journal, 39(6), 807-824.

62.O'Donnell, V. (2016). Organisational change and development towards inclusive higher education. Journal of Applied Research in Higher Education, 8(1), 101-118.

63.O'Reilly, C. \& Tushman, M. (2018). Ambidexterity as a dynamic capability: resolving the innovator's dilemma. Research in Organizational Behavior, 28, 185-206.

64.Probst, G., Raisch, S. \& Tushman, M. (2011). Ambidextrous leadership: emerging challenges for business and HR leaders. Organizational Dynamics, 40(4), 326-334.

65.Rafferty, A., Jimmieson, N. \& Armenakis, A. (2013). Change readiness: A multilevel review. Journal of Management, 39(1), 110-135.

66.Raziq, M., Borini, F., Malik, O., Ahmad, M. \& Shabaz, M. (2018). Leadership styles, goal clarity, and project success: evidence from projectbased organizations in Pakistan. Leadership \& Organization Development Journal, 39(2), 309-323.

67.Ripkey, S. (2017). Organizational change and ambidexterity in higher education: A case study of institutional merger. Research in Organizational Change and Development, 25, 285-317.

68.Rosing, K., Frese, M. \& Bausch, A. (2011). Explaining the heterogeneity of the leadership innovation relationship: ambidextrous leadership. Leadership Quarterly, 22(5), 956-974.

69.Rusly, F., Corner, J. \& Sun, P. (2012). Positioning change readiness in knowledge management research. Journal of Knowledge Management, 16(2), 329-355.

70.Rusly, F., Sun, P. \& Corner, J. (2015). Change readiness: creating understanding and capability for the knowledge acquisition process. Journal of Knowledge Management, 19(6), 1204-1223.

71.Samal, A., Patra, S. \& Chatterjee, D. (2019). Impact of culture on organizational readiness to change: context of bank M\&A. Benchmarking: An International Journal. Retrieved from https://www.emerald.com/insight/content/doi/10.1108/BIJ-10-2019- 
0454/full/pdf?title=impact-of-culture-on-organizational-readiness-tochange-context-of-bank-mampa.

72.Schell, W. (2019). Leadership and change management. In Ward, N., Watson, B. \& Fleming-Vogl, K., Traffic Safety Culture: Definition, Foundation, and Application. Emerald Publishing Limited.

73.Self, D. \& Schraeder, M. (2009). Enhancing the success of organizational change: Matching readiness strategies with sources of resistance. Leadership \& Organization Development Journal. 30(2), 167-182.

74.Shokri, A., Waring, T. \& Nabhani, F. (2016). Investigating the readiness of people in manufacturing SMEs to embark on Lean Six Sigma projects: An empirical study in the German manufacturing sector. International Journal of Operations \& Production Management. 36(8), 850-878.

75.Smulowitz, S. (2015). Evidence for the performance prism in higher education. Measuring Business Excellence, 19(1), 70-80.

76.Souza, C. \& Takahashi, A. (2019). Dynamic capabilities, organizational learning and ambidexterity in a higher education institution. The Learning Organization, 26(4), 397-411.

77.Stensaker, B., Frolich, N., Huisman, J., Waagene, E., Scordato, L. \& Botas, P. (2014). Factors affecting strategic change in higher education. Journal of Strategy and Management, 7(2), 193-207.

78.Surty, S. \& Scheepers, C. (2020). Moderating effect of environmental dynamism on leadership practices and employees' response to change in South Africa. Management Research Review, 43(7), 787-810.

79.Thakur, R. \& Srivastava, S. (2018). From resistance to readiness: the role of mediating variables. Journal of Organizational Change Management, 31(1), 230-247.

80.Thompson, S. (2012). Sampling (Third Ed.)", New Jersey, United States of America: John Wiley \& Sons, Inc.

81.Timmor, Y. \& Zif, J. (2010). Change readiness: an alternative conceptualization and an exploratory investigation. EuroMed Journal of Business, 5(2), 138-165.

82.Tung, F. (2016). Does transformational, ambidextrous, transactional leadership promote employee creativity? Mediating effects of empowerment and promotion focus. International Journal of Manpower, 37(8), 1250-1263. 83.Vaishnavi, V., Suresh, M. \& Dutta, P. (2019). A study on the influence of factors associated with organizational readiness for change in healthcare organizations using TISM. Benchmarking: An International Journal, 26(4), 1290-1313.

84.Vakola, M. (2013). Multilevel Readiness to Organizational Change: A Conceptual Approach. Journal of Change Management. Retrieved from http://dx.doi.org/10.1080/14697017.2013.768436. 
85.Vera, D. \& Crossan, M. (2004). Strategic leadership and organizational learning. Academy of Management Review, 29(2), 222-240.

86.Zacher, H. \& Rosing, K. (2015). Ambidextrous leadership and team innovation. Leadership \& Organization Development Journal, 36(1), 54-68. 87.Zacher, H., Robinson, A. \& Rosing, A. (2016).Ambidextrous leadership and employees' self-reported innovative performance: The role of exploration and exploitation behaviors. Journal of Creative Behavior, 50(1), 24-46.

88.Zaman, U., Nawaz, S., Tariq, S. \& Humayoun, A. (2020). Linking transformational leadership and "multi-dimensions" of project success Moderating effects of project flexibility and project visibility using PLSSEM. International Journal of Managing Projects in Business. 13(1), 103127.

89.Zheng, X., Liu, Z. \& Gong, X. (2016). Why does leader attention scope matter for innovation ambidexterity? The mediating role of transformational leadership. Leadership \& Organization Development Journal, 37(7), 912935.

90.Zuraik, A. \& Kelly, L. (2019). The role of CEO transformational leadership and innovation climate in exploration and exploitation. European Journal of Innovation Management, 22(1), 84-104. 
مجلة البحوث المالية والتجارية ـ المجلد (22) - العدد الرابع ـ أكتوبر 2021

\section{Appendix I:}

\section{Research Instrument}

Transformational Leadership:

\begin{tabular}{r|r|r|r|r|}
\hline $\begin{array}{r}\text { 5: Totally } \\
\text { agree }\end{array}$ & $4:$ Agree & $3:$ Neutral & 2 : Disagree & $\begin{array}{r}1: \text { Totally } \\
\text { disagree }\end{array}$ \\
\hline \hline
\end{tabular}

Idealized Influence:

\begin{tabular}{|l|l||l||l||l||l||l||}
\hline 5 & 4 & 3 & 2 & 1 & \multicolumn{1}{|c||}{ Question } & No. \\
\hline \hline & & & & & $\begin{array}{l}\text { Instills pride in for being associated with } \\
\text { him/her. }\end{array}$ & 1. \\
\hline \hline & & & & & $\begin{array}{l}\text { Goes beyond self-interest for the good of the } \\
\text { group. }\end{array}$ & 2. \\
\hline \hline & & & & & Acts in ways that builds respect. & 3. \\
\hline \hline & & & & & $\begin{array}{l}\text { Considers the moral and ethical } \\
\text { consequences of decisions. }\end{array}$ & 4. \\
\hline \hline & & & & & Displays a sense of power and confidence. & 5. \\
\hline
\end{tabular}

Inspirational motivation:

\begin{tabular}{||l|l||l|l||l||l||l||}
\hline 5 & 4 & 3 & 2 & 1 & \multicolumn{1}{|c||}{ Question } & No. \\
\hline \hline & & & & & Talks optimistically about the future. & 6. \\
\hline & & & & & Articulates a compelling vision of the future. & 7. \\
\hline & & & & & $\begin{array}{l}\text { Emphasize the importance of having a } \\
\text { collective sense of mission. }\end{array}$ & 8. \\
\hline \hline & & & & & $\begin{array}{l}\text { Expresses with few simple words what } \\
\text { could and should be done. }\end{array}$ & 9. \\
\hline \hline & & & & & Help others find meaning to their work. & 10. \\
\hline
\end{tabular}

Intellectual Stimulation:

\begin{tabular}{||l|l||l|l||l||l||l||}
\hline 5 & 4 & 3 & 2 & 1 & \multicolumn{1}{|c||}{ Question } & No. \\
\hline \hline & & & & & $\begin{array}{l}\text { Seeks differing perspectives when solving } \\
\text { problems. }\end{array}$ & 11. \\
\hline \hline & & & & & $\begin{array}{l}\text { Provide others with new ways of looking at } \\
\text { puzzling things. }\end{array}$ & 12. \\
\hline & & & & & $\begin{array}{l}\text { Get others to rethink ideas that they had } \\
\text { never questioned before. }\end{array}$ & 13. \\
\hline & & & & & $\begin{array}{l}\text { Get others to look at problems from many } \\
\text { different angles. }\end{array}$ & 14. \\
\hline
\end{tabular}


Individual Readiness for Change; the Dyadic of Transformational Leadership and Ambidextrous Behaviors....................Abuzid and Abu-Tabl

\begin{tabular}{|l|l|l||l|l||l||}
\hline \hline & & & $\begin{array}{l}\text { Suggest new ways of looking at how to } \\
\text { complete assignments. }\end{array}$ & 15. \\
\hline
\end{tabular}

Individualized Consideration:

\begin{tabular}{|l|l||l||l||l||l||l||}
\hline \hline 5 & 4 & 3 & 2 & 1 & \multicolumn{1}{|c|}{ Question } & No. \\
\hline \hline & & & & & $\begin{array}{l}\text { Treats others as individuals rather than just } \\
\text { a member of the group. }\end{array}$ & 16. \\
\hline \hline & & & & & $\begin{array}{l}\text { Considers different needs, abilities and } \\
\text { aspirations }\end{array}$ & 17. \\
\hline & & & & & Spends time coaching and mentoring. & 18. \\
\hline & & & & & Help others develop themselves. & 19. \\
\hline \hline & & & & $\begin{array}{l}\text { Expresses satisfaction when others meet } \\
\text { expectations. }\end{array}$ & 20. \\
\hline
\end{tabular}

Ambidextrous Leadership:

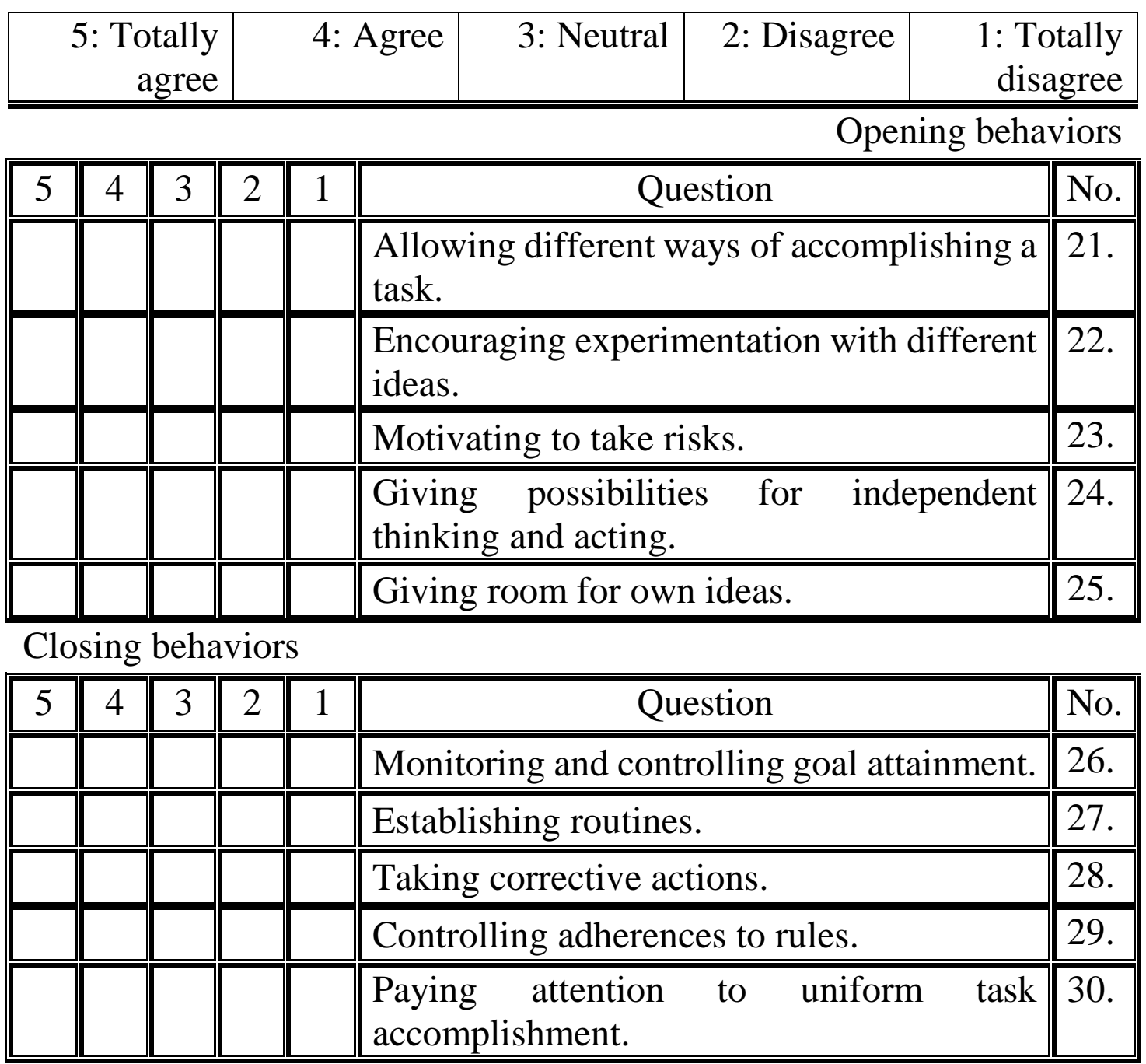


Individual Readiness for Change:

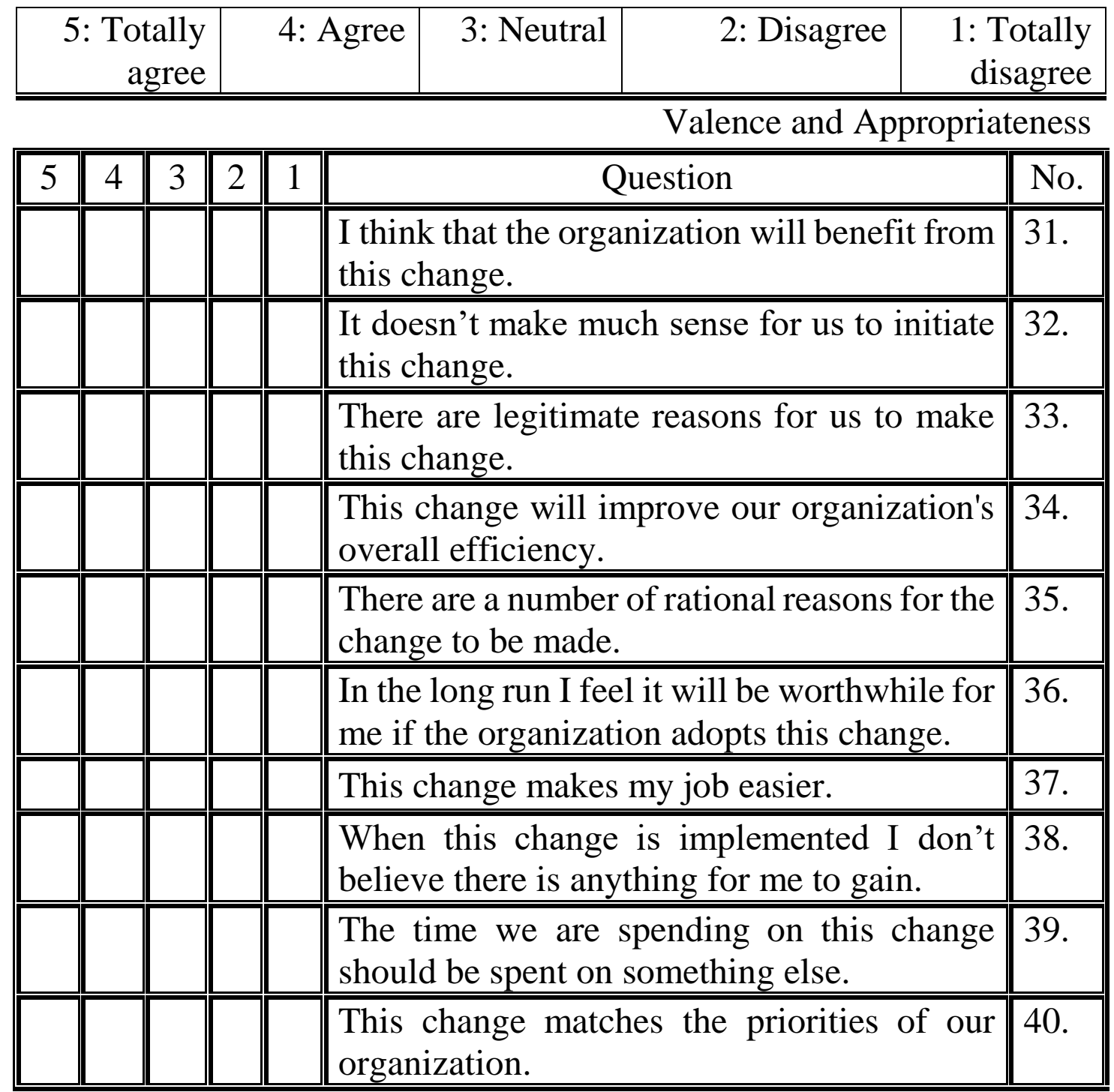

\begin{tabular}{|l|l|l|l||l||l||}
\hline \multicolumn{2}{|l||}{ Personal Benefits } \\
\hline
\end{tabular}


Individual Readiness for Change; the Dyadic of Transformational Leadership and Ambidextrous Behaviors....................Abuzid and Abu-Tabl

\begin{tabular}{l}
\hline \hline Additional Information \\
\begin{tabular}{|c||c||c||c||c||}
\hline $\begin{array}{c}\text { Teaching } \\
\text { Assistant }\end{array}$ & $\begin{array}{c}\text { Assistant } \\
\text { Professor }\end{array}$ & $\begin{array}{c}\text { Associate } \\
\text { Professor }\end{array}$ & Professor & Job Title: \\
\hline \hline Private & \multicolumn{2}{|c||}{ Public } & Type of employer (University): \\
\hline $\begin{array}{c}\text { more than 15 } \\
\text { years }\end{array}$ & $\begin{array}{c}10-14 \\
\text { years }\end{array}$ & $5-9$ years & $\begin{array}{c}\text { less than 5 } \\
\text { years }\end{array}$ & Tenure: \\
\hline $\begin{array}{c}\text { older than 50 } \\
\text { years old }\end{array}$ & $40-49$ & $30-39$ & $20-29$ & $\begin{array}{c}\text { Age } \\
\text { group: }\end{array}$ \\
\hline \hline Female & \multicolumn{3}{|c||}{ Male } & Gender: \\
\hline
\end{tabular}
\end{tabular}

